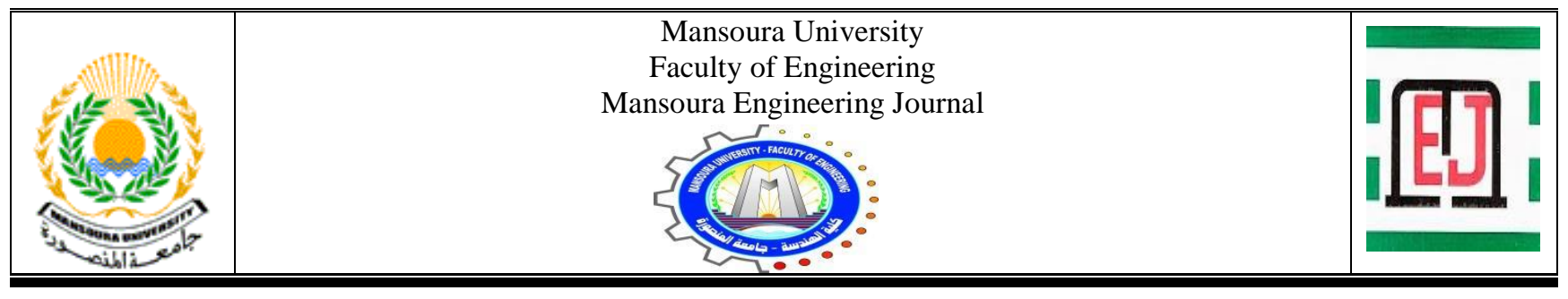

\title{
Comparison Between Different Steel Codes in Design of Bolted Connection Under Shear and Tension
}

\begin{tabular}{|l|}
\hline KEYWORDS: \\
Bolted connection, Bolts \\
grades, rurocode, \\
Egyptian codes, AISC- \\
360 \\
\\
\end{tabular}

\author{
D.A. Eltawil, F.A. Salem and N.S. Mahmoud
}

\section{INTRODUCTION}

$\mathrm{C}$ ONNECTIONS represent an important part of each structure and are more conservative than members. Given that connections are more difficult to evaluate than members, a big discrepancy exists between analysis and actual behavior. The choice to use a specific form of connection is solely that of the designer, and he should decide by knowing the behavior of connection, economy, and

Received: Received: (9 November, 2020) - Revised: (25 January, 2021) Accepted: (17 February, 2021)

Corresponding Author: D.A. Eltawil, Structural Engineering department, Faculty of Engineering, Mansoura University, Egypt (engdinaeltawil@yahoo.com).

Assist. Prof. Dr. F.A. Salem, Structural Engineering department, Faculty of Engineering, Mansoura University, Egypt (drfikry_salem@yahoo.com).

Prof. Dr. N.S. Mahmoud, Structural Engineering department, Faculty of Engineering, Mansoura University,Egypt(nsm_eco@yahoo.com). construction speed [1]. Two kinds of forces, namely, tension and shear forces, should be considered in bolt design. The bolted connection may be categorized into ordinary or highstrength connection, which are simple to install and especially convenient for connection in construction sites [2].

Scholars have compared the building codes for Eurocode 4 (EC4) and AISC 360 by analyzing circular CFST (ConcreteFilled Steel Tube) columns below the hub stack and assessing how well the column's true behavior is explained by a sequence of observable comparisons [3]. Other researchers have focused on dealing with unbraced steel frames primarily by numerous structural analysis approaches [4]. Building construction codes in the USA, Europe, and Egypt are compared, with emphasis on action (loads) values and section resistance in bending and compression axial loads [5].

T H Gebre [6] has compared AISC-LRFD, European, and Russian (SP) codes, taking into account the strength of steel members subjected to various loads. In Xiao and Ishikawa, McCarthy et al. [7], have developed finite-element analyses and experimental study for bolted joints used for high-strength 
steel. Maiorana and Pellegrino [8] have compared the Eurocode to Italy, the United States, Canada, Australia, and Japan codes. The general design requirements for typical connections in bridges is discussed, as well as the geometrical limitations, and slip, shear, and bearing resistance.

Numerous developments have been achieved in study of structural engineering in the past two decades. The knowledge of structural theory has developed, and the use of computerassisted configuration has supported further advances in elastic and inelastic research of steel structures. Construction methods and steel quality are constantly improving, leading to development of "rational design technique." Design in steel is used to be seen as a "black art," where, After 20 years of hard work and experience, a certain degree of competence has been achieved [9].

Although experience remains important, the designer is now better supported and is more exact by using computer program. Computers render empirical standards, which would have been easier in manual statistics. Practice codes have become more specific [10]. Construction, assemble, and installation of steel frameworks at many locations become feasible due to rapid globalization [4].

The Egyptian Code of Practice for Steel Construction (ECP) was established in Egypt by the National Research Center for Housing and Construction; this code is split into the Egyptian Code of Practice for Steel Construction (LRFD) [11] and the Egyptian Code of Practice for Steel Construction and Bridges (ASD) [12].

"Specifications for Structural Steel Buildings (2016) [13]" was developed by the American Institute of Steel Construction (AISC) in the United States. The AISC 360-16 specification uses the Load and Resistance Factor Design (LRFD) and the Allowable Strength Design (ASD) formats. In general, the AISC 360-16 specification has limitations for the design of a given load, and either the LRFD or ASD format uses nominal force depending on limit states. Resistance factor $(\phi)$

TABLE II

\begin{tabular}{|c|c|c|c|c|c|c|c|c|c|c|c|c|}
\hline \multirow{5}{*}{$\begin{array}{c}\text { AISC } \\
{[21]}\end{array}$} & \multicolumn{10}{|c|}{ BOLT GRADE EQUIVALENT } & \multirow{2}{*}{\multicolumn{2}{|c|}{$\mathbf{C}$}} \\
\hline & Group & \multicolumn{5}{|c|}{-} & \multicolumn{2}{|c|}{$\mathbf{A}$} & \multicolumn{2}{|l|}{ B } & & \\
\hline & $\begin{array}{c}\text { ASTM } \\
\text { Designation }\end{array}$ & \multicolumn{2}{|c|}{ Gr. A307 } & \multicolumn{3}{|l|}{-} & $\begin{array}{c}\text { F3125 / } \\
\text { F3125M } \\
\text { Gr. A325 / } \\
\text { Gr. A325M }\end{array}$ & $\begin{array}{c}\text { A35 } \\
4 \\
\text { Gr. } \\
\text { BC }\end{array}$ & $\begin{array}{c}\text { F3125 / } \\
\text { F3125M } \\
\text { Gr. A490 / Gr. } \\
\text { A490M }\end{array}$ & $\begin{array}{c}\text { A354 } \\
\text { Gr. BD }\end{array}$ & F3040 & F3111 \\
\hline & $\begin{array}{c}F_{\mathrm{y}} \\
\text { Minimum yield } \\
\text { stress MPa (ksi) }\end{array}$ & \multicolumn{2}{|l|}{-} & \multicolumn{3}{|l|}{-} & - & $\begin{array}{l}683 \\
(99)\end{array}$ & - & $\begin{array}{l}794 \\
(115)\end{array}$ & - & - \\
\hline & $\begin{array}{c}F_{\mathrm{u}} \\
\text { Minimum tensile } \\
\text { stress } \mathrm{MPa}(\mathrm{ksi})\end{array}$ & \multicolumn{2}{|c|}{$414(60)$} & \multicolumn{3}{|l|}{ - } & $828(120)$ & $\begin{array}{l}794 \\
(115\end{array}$ & $1035(150)$ & $\begin{array}{l}966 \\
(140)\end{array}$ & $\begin{array}{l}1380 \\
(200)\end{array}$ & $1380(200)$ \\
\hline \multirow{3}{*}{$\begin{array}{l}\mathbf{E C 3} \\
{[22]}\end{array}$} & Bolt grade & 4.6 & 4.8 & 5.6 & 5.8 & 6.8 & \multicolumn{2}{|l|}{8.8} & \multicolumn{2}{|l|}{10.9} & \multicolumn{2}{|l|}{-} \\
\hline & $\begin{array}{c}F_{\mathrm{yb}} \\
\text { Minimum yield } \\
\text { stress MPa (ksi) }\end{array}$ & $\begin{array}{l}240 \\
(35)\end{array}$ & $\begin{array}{l}320 \\
(46)\end{array}$ & $\begin{array}{l}300 \\
(44)\end{array}$ & $\begin{array}{l}400 \\
(58)\end{array}$ & $\begin{array}{l}480 \\
(70)\end{array}$ & \multicolumn{2}{|l|}{$640(93)$} & \multicolumn{2}{|l|}{$900(130)$} & \multicolumn{2}{|l|}{-} \\
\hline & $\begin{array}{c}F_{u b} \\
\text { Minimum tensile } \\
\text { stress MPa (ksi) }\end{array}$ & $\begin{array}{l}400 \\
(58)\end{array}$ & $\begin{array}{l}400 \\
(58)\end{array}$ & $\begin{array}{l}500 \\
(72)\end{array}$ & $\begin{array}{l}500 \\
(72)\end{array}$ & $\begin{array}{l}600 \\
(87)\end{array}$ & \multicolumn{2}{|l|}{$800(116)$} & \multicolumn{2}{|l|}{$1000(145)$} & \multicolumn{2}{|l|}{-} \\
\hline \multirow{3}{*}{$\begin{array}{c}\mathbf{E C P} \\
{[12]}\end{array}$} & Bolt grade & 4.6 & 4.8 & 5.6 & 5.8 & 6.8 & \multicolumn{2}{|l|}{8.8} & \multicolumn{2}{|l|}{10.9} & \multicolumn{2}{|l|}{-} \\
\hline & $\begin{array}{c}F_{\mathrm{yb}} \\
\text { Minimum yield } \\
\text { stress } \mathrm{MPa}\left(\mathrm{t} / \mathrm{cm}^{2}\right)\end{array}$ & $\begin{array}{l}240 \\
(2.4)\end{array}$ & $\begin{array}{l}320 \\
(3.2)\end{array}$ & $\begin{array}{l}300 \\
(3)\end{array}$ & $\begin{array}{l}400 \\
(4)\end{array}$ & $\begin{array}{l}480 \\
(4.8)\end{array}$ & \multicolumn{2}{|l|}{$640(6.4)$} & \multicolumn{2}{|l|}{$900(9)$} & \multicolumn{2}{|c|}{-} \\
\hline & $\begin{array}{c}F_{u b} \\
\text { Minimum tensile } \\
\text { stress } \mathrm{MPa}\left(\mathrm{t} / \mathrm{cm}^{2}\right)\end{array}$ & $\begin{array}{l}400 \\
(4)\end{array}$ & $\begin{array}{l}400 \\
(4)\end{array}$ & $\begin{array}{l}500 \\
(5)\end{array}$ & $\begin{array}{l}500 \\
(5)\end{array}$ & $\begin{array}{l}600 \\
(6)\end{array}$ & \multicolumn{2}{|l|}{$800(8)$} & \multicolumn{2}{|l|}{$1000(10)$} & \multicolumn{2}{|c|}{-} \\
\hline
\end{tabular}

multiplies the nominal strength in the LRFD format.

In Europe, "Design of Steel Structures EN 1993 (2003)" was drawn by the European Committee for Standardization [14]. This specification, alluded to the EC3 specification, was established using partial safety factor $\left(\gamma_{M}\right)$ to limit the principles of the state. In general, a partial safety factor divides the characteristic resistance and then compares it to the factored loads [15].

This work compares bolted connection capability among Egyptian ECP [12][11], American AISC [13], and Eurocode part 1.8 [16] to (i) recognize similarities and differences in strength calculated and (ii) encourage accelerated learning with the previous know-how of one code. This paper focuses on resistance to tension, shear, and shear and tension combination to steel components under each load case.

\section{Steel Grades in ACCORdance WITH ECP, AISC, AND EC3 Provisions}

Steel grades used for structural shapes certified by AISC are grouped as follows: carbon steel [A36, A529 Gr. (50,55), and A709 Gr. (36)], low-alloy high-strength steel [A572 Gr. (42,50,55,60,65), A709, A913, and A992], and low-alloy high-strength corrosion-resistant steel (A588) [13]. For ECP, steel grades used are St37, St44, and St52 [12]. For EC3, steel grades utilized are S275, S355, and S450 [17]. Table (I) lists the steel grade equivalences in ECP, AISC, and EC3 from steel grades referred to above.

TABLE I

EQUIVALENT OF STEEL GRADE

\begin{tabular}{l||l||l}
\multicolumn{1}{c||}{ ECP } & \multicolumn{1}{c||}{ AISC } & \multicolumn{2}{c}{ EC3 } \\
\hline St37 & A36 & S235 \\
\hline St44 & A572 Gr.42 & S275 \\
\hline St52 & A992 & S355
\end{tabular}




\section{ECP, AISC, AND EC3 Provisions FOR BOLT GRADES}

The AISC specification for the use of high-strength bolts shall conform with the specifications of the Research Council's Structural Joints Specification, as certified by the Structural Connections Research Council. The EC3 specification presents rules based on the ISO-898 (1999) standard of the International Standardization Organization for the widely used bolt grades in Europe. Table (II) lists the bolt grade equivalences in ECP, AISC, and EC3.

\section{COMPaRison OF DiSTANCE BETWEen BolT'S HoleS}

To determine differences between ECP, AISC, and EC3, we compared minimum and maximum spacing and edge distances, but for EC3 $\mathrm{d}_{0}=\mathrm{d}+(1 \mathrm{~mm}$ for M12 and M14, 2 $\mathrm{mm}$ for M16 up to M24, and $3 \mathrm{~mm}$ for M27 and larger bolts). All equations were collected to compare codes illustrated in Table (III).

The AISC offers more conservative results for the minimum edge and end distance than those in ECP and EC3 (Figs. 1), but the EC3 offers more conservative results for the minimum spacing between centers of fasteners in the direction of load transfer and perpendicularly to the direction of load transfer than those in ECP and AISC (Figs. 2 and 3).

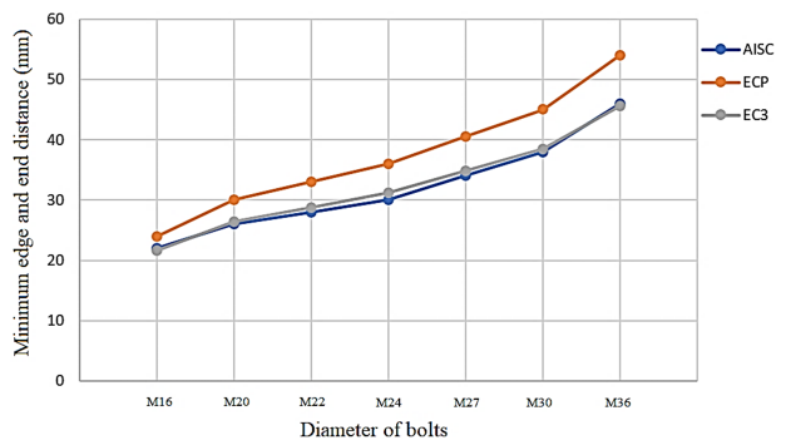

Fig. 1. Comparison of minimum edge and end distance for common bolt diameters

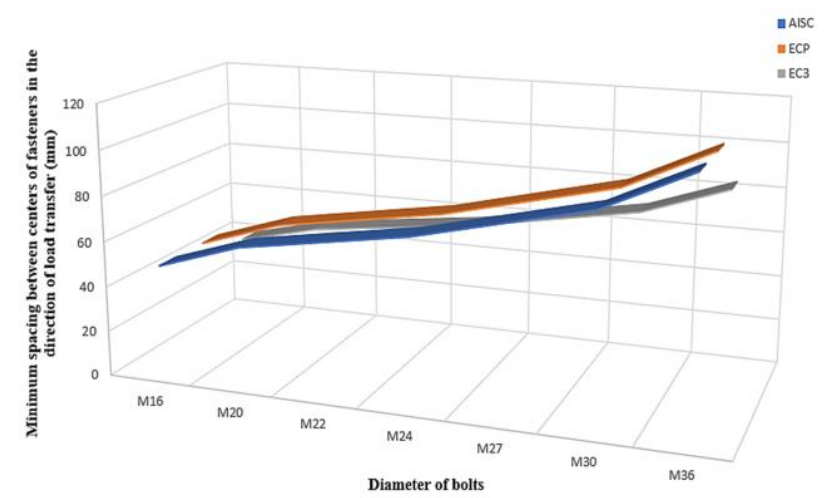

Fig. 2. Comparison of minimum spacing between centers of fasteners in the direction of load transfer for common bolt diameters

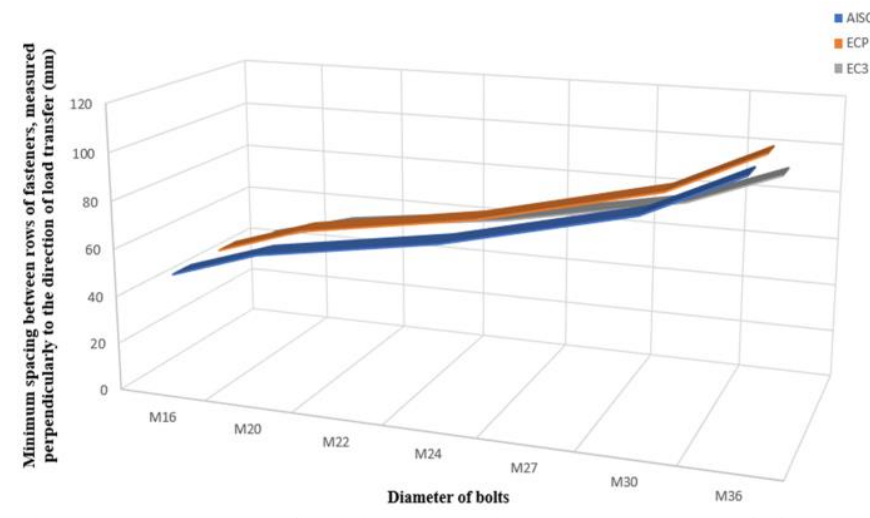

Fig. 3. Comparison of minimum spacing between rows of fasteners, measured perpendicularly to the direction of load transfer for common bolt diameters

TABLE III

\begin{tabular}{|c|c|c|c|c|}
\hline DISTANCE AND SPACING & EDGE DISTANCE & $\begin{array}{l}\text { JM AND MAXIMUM SPACINC } \\
\text { END DISTANCE }\end{array}$ & $\begin{array}{l}\text { ND, AND EDGE DISTANCES } \\
\text { SPACING BETWEEN CENTERS } \\
\text { OF FASTENERS IN THE } \\
\text { DIRECTION OF LOAD } \\
\text { TRANSFER }\end{array}$ & $\begin{array}{l}\text { SPACING BETWEEN ROWS OF } \\
\text { FASTENERS, MEASURED } \\
\text { PERPENDICULARLY TO THE } \\
\text { DIRECTION OF LOAD TRANSFER }\end{array}$ \\
\hline \multicolumn{5}{|c|}{ MINIMUM } \\
\hline AISC & $\begin{array}{l}\text { dependent on the bolt } \\
\text { diameter }\end{array}$ & $\begin{array}{l}\text { dependent on the bolt } \\
\text { diameter }\end{array}$ & $3 \mathrm{~d}$ & $3 \mathrm{~d}$ \\
\hline ECP & $1.5 \mathrm{~d}$ & $1.5 \mathrm{~d}$ & $3 \mathrm{~d}$ & $3 \mathrm{~d}$ \\
\hline EC3 & $1.2 \mathrm{~d}_{0}$ & $1.2 \mathrm{~d}_{0}$ & $2.2 \mathrm{~d}_{0}$ & $2.4 \mathrm{~d}_{0}$ \\
\hline \multicolumn{5}{|c|}{ MAXIMUM } \\
\hline AISC & $\begin{array}{l}\text { The lesser one of }(12 \mathrm{t} \\
\& 150 \mathrm{~mm})\end{array}$ & $\begin{array}{l}\text { The lesser one of }(12 \mathrm{t} \& \\
150 \mathrm{~mm})\end{array}$ & $\begin{array}{l}\text { The lesser one of }(14 \mathrm{t} \& 180 \\
\mathrm{mm})\end{array}$ & The lesser one of $(14 \mathrm{t} \& 180 \mathrm{~mm})$ \\
\hline ECP & $12 \mathrm{t}$ & $12 \mathrm{t}$ & $\begin{array}{l}\text { The lesser one of }(14 \mathrm{t} \& 200 \\
\mathrm{mm})\end{array}$ & The lesser one of $(14 \mathrm{t} \& 200 \mathrm{~mm})$ \\
\hline EC3 & $\begin{array}{l}\text { The larger one of }(8 \mathrm{t} \\
\& 125 \mathrm{~mm})\end{array}$ & $\begin{array}{l}\text { The larger one of }(8 \mathrm{t} \& \\
125 \mathrm{~mm})\end{array}$ & $\begin{array}{l}\text { The lesser one of }(14 \mathrm{t} \& 175 \\
\mathrm{mm})\end{array}$ & The lesser one of $(14 \mathrm{t} \& 175 \mathrm{~mm})$ \\
\hline
\end{tabular}

$\mathrm{d}=$ bolt diameter, $\mathrm{d}_{0}=$ hole diameter, $\mathrm{t}=$ the thickness of the smallest connected 


\section{BOLT STRENGTH UNDER SHEAR IN BEARING TYPE CONNECTIONS}

In accordance with AISC-360 and EC3 specifications, the shear rupture along the threaded or unthreaded portion is known as the ultimate limit state for bolts under the action of shear forces. In the AISC 360-16 specification, nominal strength is dependent on the bolt's tensile strength and the position of the shear plane with respect to the bolt threads for the limit state of bolt shear. In the EC3 specification, when the threads are in the shear plane, the net shear area must be calculated through the threads. In the ECP codes, threads are in the shear plane, and stress area must be calculated through the threads. The shear capacity for bolts is determined as follows:

$$
\begin{aligned}
, \mathrm{R}_{\mathrm{n}} & =\phi \mathrm{F}_{\mathrm{n}} \mathrm{A}_{\mathrm{b}} \\
\mathrm{R}_{\mathrm{n}} / \Omega & =\mathrm{F}_{\mathrm{n}} \mathrm{A}_{\mathrm{b}} / \Omega \\
{ }_{\mathrm{v}, \mathrm{Rd}} & =\frac{\alpha_{\mathrm{v}} \mathrm{f}_{\mathrm{ub}} \mathrm{A}}{\gamma_{\mathrm{M} 2}} \\
{ }_{\mathrm{v}} \mathrm{R}_{\mathrm{nv}} & =\left(0.6 \mathrm{~F}_{\mathrm{ub}}\right) \mathrm{A}_{\mathrm{s}} \\
{ }_{\mathrm{v}} \mathrm{R}_{\mathrm{nv}} & =\left(0.5 \mathrm{~F}_{\mathrm{ub}}\right) \mathrm{A}_{\mathrm{s}} \\
\mathrm{R}_{\mathrm{sh}} & =0.25 \mathrm{~F}_{\mathrm{ub}} \mathrm{A}_{\mathrm{s}} \\
\mathrm{R}_{\mathrm{sh}} & =0.2 \mathrm{~F}_{\mathrm{ub}} \mathrm{A}_{\mathrm{s}}
\end{aligned}
$$

For AISC (LRFD)

For AISC (ASD)

For EC3

For ECP (LRFD)

For ECP (LRFD)

For ECP (ASD)

For ECP (ASD)

In these equations:

$$
\begin{aligned}
& \mathrm{R}_{\mathrm{n}} \quad=\text { nominal strength } \\
& \mathrm{F}_{\mathrm{n}} \quad=\text { shear stress, } \mathrm{F}_{\mathrm{nv}} \\
& \mathrm{A}_{\mathrm{b}} \quad=\text { bolt nominal unthreaded or threaded body } \\
& \text { area } \\
& \phi \quad=0.75 \\
& \Omega \quad=2.0 \\
& v, \mathrm{Rd}=\text { design resistance of bolts in shear } \\
& \mathrm{f}_{\mathrm{ub}}=\text { the ultimate tensile strength nominal value } \\
& \text { for bolts } \\
& \text { A }=\text { the bolt tensile stress area }=\mathrm{A}_{\mathrm{s}} \\
& { }_{\mathrm{M} 2}=\text { the partial factor for resistance of bolts }=1.25 \\
& \mathrm{R}_{\mathrm{nv}} \quad=\text { shear strength of the design } \\
& \phi_{\mathrm{v}} \quad=0.6 \\
& \text { ub } \quad=\text { ultimate tensile strength for bolts } \\
& \mathrm{A}_{\mathrm{s}} \quad=\text { the bolt tensile stress area } \\
& 2_{\mathrm{sh}} \quad=\text { design bolt shear strength }
\end{aligned}
$$

Equations (4 and 6) are used for bolt grades 4.6, 5.6, and 8.8, and Equations (5 and 7) are used for bolt grades 4.8, 5.8, 6.8, and 10.9. The Eurocode offers more conservative results for the shear strength of various bolt grades than those in American and Egyptian codes (Figs. 4 and 5).

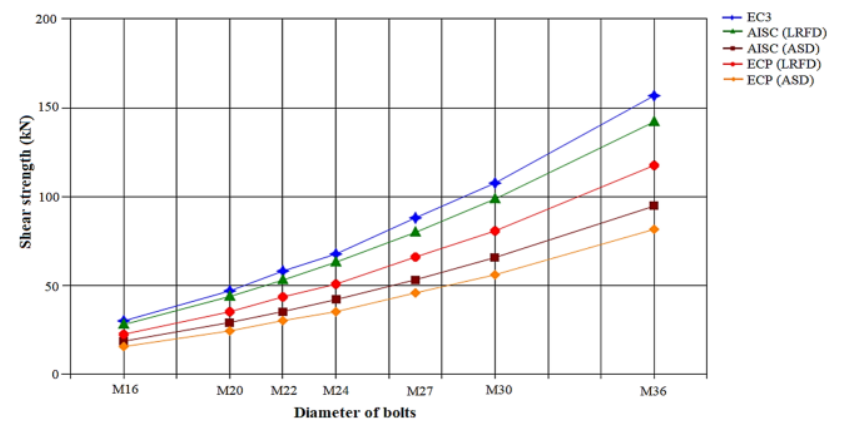

Fig. 4. Comparison of shear strength for common bolt diameters (grade 4.6)

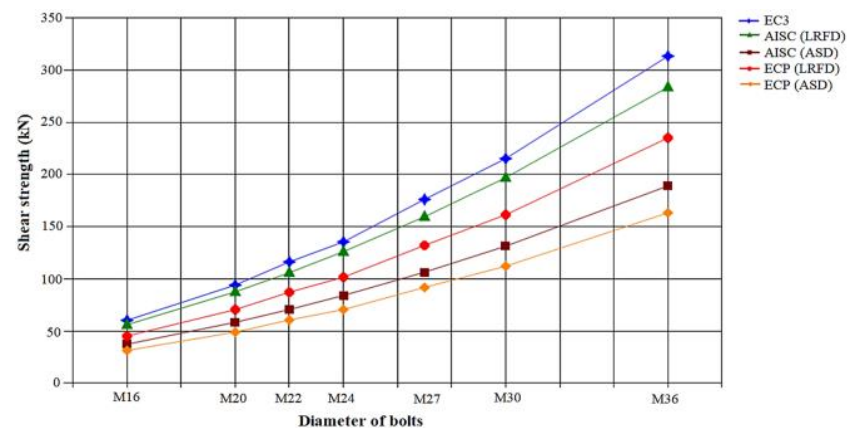

Fig. 5. Comparison of shear strength for common bolt diameters (grade 8.8)

\section{BOLT STRENGTH UNDER TENSION IN BEARING TYPE CONNECTIONS}

According to EC3 and AISC-360 specifications, tensile rupture along the threaded portion is known as the ultimate limit state for bolts under the action of tensile forces. In the AISC-360 specification, for the tension limit state of bolts, strength is directly dependent on the tensile strength of the material of the bolt. In the EC3 specification, the resistance to the design tension of the bolt is calculated in compliance with Part 1-8 of Eurocode 3. In the ECP codes, the nominal tension strength for bolt grades is the basis for design of tension strength for LRFD. The tension strength for ASD is centered based on the allowable tensile bolt stress and the area of bolt stress. Tensile capacity is calculated as follows:

$$
\begin{aligned}
p \mathrm{R}_{\mathrm{n}} & =\mathrm{F}_{\mathrm{n}} \mathrm{A}_{\mathrm{b}} & & \text { For AISC (LRFD) } \\
\mathrm{R}_{\mathrm{n}} / \Omega & =\mathrm{F}_{\mathrm{n}} \mathrm{A}_{\mathrm{b}} / \Omega & & \text { For AISC (ASD) } \\
{ }_{\mathrm{t}, \mathrm{Rd}} & =\frac{\mathrm{f}_{\mathrm{ub}} \mathrm{A}_{\mathrm{s}}}{\mathrm{r}_{\mathrm{M} 2}} & & \text { For EC3 } \\
{ }_{\mathrm{t}} \mathrm{R}_{\mathrm{nt}} & \left.=6 \mathrm{~F}_{\mathrm{ub}}\right) \mathrm{A}_{\mathrm{s}} & & \text { For ECP (LRFD) } \\
{ }_{\mathrm{t}} \mathrm{R}_{\mathrm{nt}} & \left.=3 \mathrm{~F}_{\mathrm{ub}}\right) \mathrm{A}_{\mathrm{s}} & & \text { For ECP (LRFD) } \\
\mathrm{R}_{\mathrm{t}} & =\mathrm{F}_{\mathrm{ub}} \mathrm{A}_{\mathrm{s}} & & \text { For ECP (ASD) }
\end{aligned}
$$


In these equations:

$$
\begin{array}{ll}
F_{n} & =\text { tensile stress, } F_{n t} \\
\phi & =0.75 \\
\Omega & =2.0 \\
F_{t, R d} & =\text { design resistance of bolts in tension } \\
A_{\mathrm{s}} & =\text { the tensile stress area for the bolt } \\
{ }^{M} 2 & =\text { the partial factor for resistance of bolts }=1.25 \\
R_{n t} & =\text { the design tension strength } \\
\phi_{\mathrm{t}} & =0.7 \\
\mathrm{R}_{\mathrm{t}} & =\text { the tensile strength of the bolt }
\end{array}
$$

Equation (11) is used for bolt grades 4.6, 4.8, 5.6, 5.8, and 6.8, and Equation (12) is used for bolt grades 8.8 and 10.9. More conservative findings for tensile strength for various bolt grades were obtained in AISC (LRFD) than those in Eurocode, AISC (ASD), and Egyptian codes (Figs. 6 and 7).

\section{Bolt Strength Under Combined Tension AND SHEAR IN BEARING TYPE CONNECTIONS}

In the AISC-360 specification, the interaction between shear and tension is best described by an elliptic relation [18][19]. In the EC3 specification, the interaction between shear and tension is best defined by a straight line [20]. In the ECP codes, the equations are an elliptic relation when bolts are prone to shear and tension combinations [11] [12], as shown in (Fig. 8). The interaction equation is presented as follows:

$$
\begin{array}{ll}
\left(\frac{\mathrm{T}_{\mathrm{u}}}{\left(\phi \mathrm{R}_{\mathrm{n}}\right)_{\mathrm{t}}}\right)^{2}+\left(\frac{\mathrm{V}_{\mathrm{u}}}{\left(\phi \mathrm{R}_{\mathrm{n}}\right)_{\mathrm{v}}}\right)^{2} \leq 1.0 & \text { For AISC (LRFD) } \\
\left(\frac{\mathrm{T}_{\mathrm{a}}}{\left(\mathrm{R}_{\mathrm{n}} / \Omega\right)_{\mathrm{t}}}\right)^{2}+\left(\frac{\mathrm{V}_{\mathrm{a}}}{\left(\mathrm{R}_{\mathrm{n}} / \Omega\right)_{\mathrm{v}}}\right)^{2} \leq 1.0 & \text { For AISC (ASD) } \\
\frac{\mathrm{F}_{\mathrm{v}, \mathrm{Ed}}}{\mathrm{F}_{\mathrm{v}, \mathrm{Rd}}}+\frac{\mathrm{F}_{\mathrm{t}, \mathrm{Ed}}}{1.4 \mathrm{~F}_{\mathrm{t}, \mathrm{Rd}}} \leq 1.0 & \text { For EC.3 } \\
\left(\frac{\mathrm{R}_{\mathrm{ut}}}{\phi_{\mathrm{t}} \mathrm{R}_{\mathrm{nt}}}\right)^{2}+\left(\frac{\mathrm{R}_{\mathrm{uv}}}{\phi_{\mathrm{v}} \mathrm{R}_{\mathrm{nv}}}\right)^{2} \leq 1.0 & \text { For ECP (LRFD) } \\
\left(\frac{\mathrm{R}_{\mathrm{sh}, \mathrm{a}}}{\mathrm{R}_{\mathrm{sh}}}\right)^{2}+\left(\frac{\mathrm{R}_{\mathrm{t}, \mathrm{a}}}{\mathrm{R}_{\mathrm{t}}}\right)^{2} \leq 1.0 & \text { For ECP (ASD) }
\end{array}
$$

In these equations:

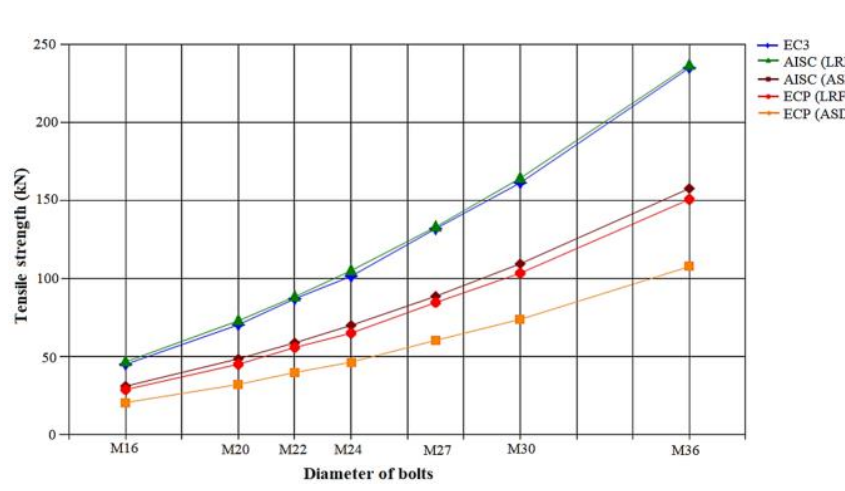

Fig. 6. Comparison of tensile strength for common bolt diameters (grade 4.6)
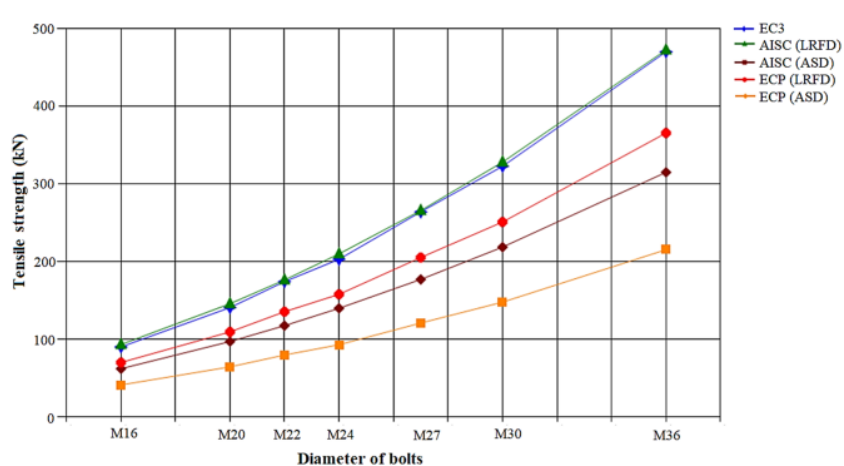

Fig. 7. Comparison of tensile strength for common bolt diameters (grade 8.8)
$\mathrm{T}_{\mathrm{u}} \quad=$ required tension strength (factored tensile load) per bolt

$\begin{aligned}\left(\phi \mathrm{R}_{\mathrm{n}}\right)_{\mathrm{t}} & =\text { design strength in tension } \\ & =\text { required shear strength (factored shear load) }\end{aligned}$ per bolt

$\left.\phi \mathrm{R}_{\mathrm{n}}\right)_{\mathrm{v}}=$ design strength in shear

$=$ required tension strength (service tensile

a $\quad=$ load) per bolt

$\left.\mathrm{R}_{\mathrm{n}} / \Omega\right)_{\mathrm{t}}=$ allowable strength in tension

a $=$ required shear strength (service shear load) per bolt

$\left.R_{n} / \Omega\right)_{v}=$ allowable strength in shear

$\phi \quad=0.75$

$\Omega \quad=2.0$

$\mathrm{v}, \mathrm{Ed}=$ the shear load in a bolt

$\mathrm{t}$ Ed $=$ load of tension in a bolt

ut $\quad=$ factored tension load on bolt

${ }_{\mathrm{t}} \mathrm{R}_{\mathrm{nt}}=$ design strength of bolt in tension alone

uv $\quad=$ factored shear load on bolt

$\phi_{\mathrm{v}} \mathrm{R}_{\mathrm{nv}}=$ design strength of bolt in shear alone

$\phi_{\mathrm{t}} \quad=0.7$

$\phi_{\mathrm{v}} \quad=0.6$

$=$ the actual shearing force in the bolt because of the applied shear force

$\mathrm{R}_{\mathrm{t}, \mathrm{a}}=$ the actual tension force in the bolt because of the tension force applied 


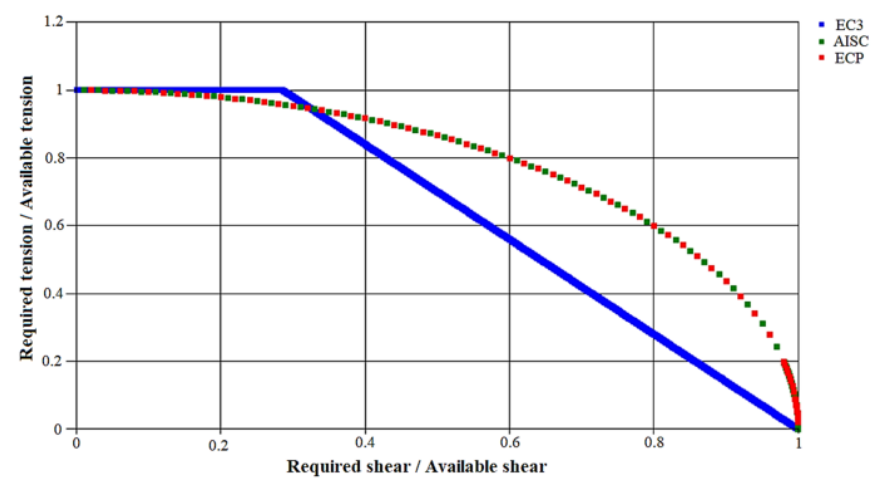

Fig. 8. Comparison of combined tension and shear strength

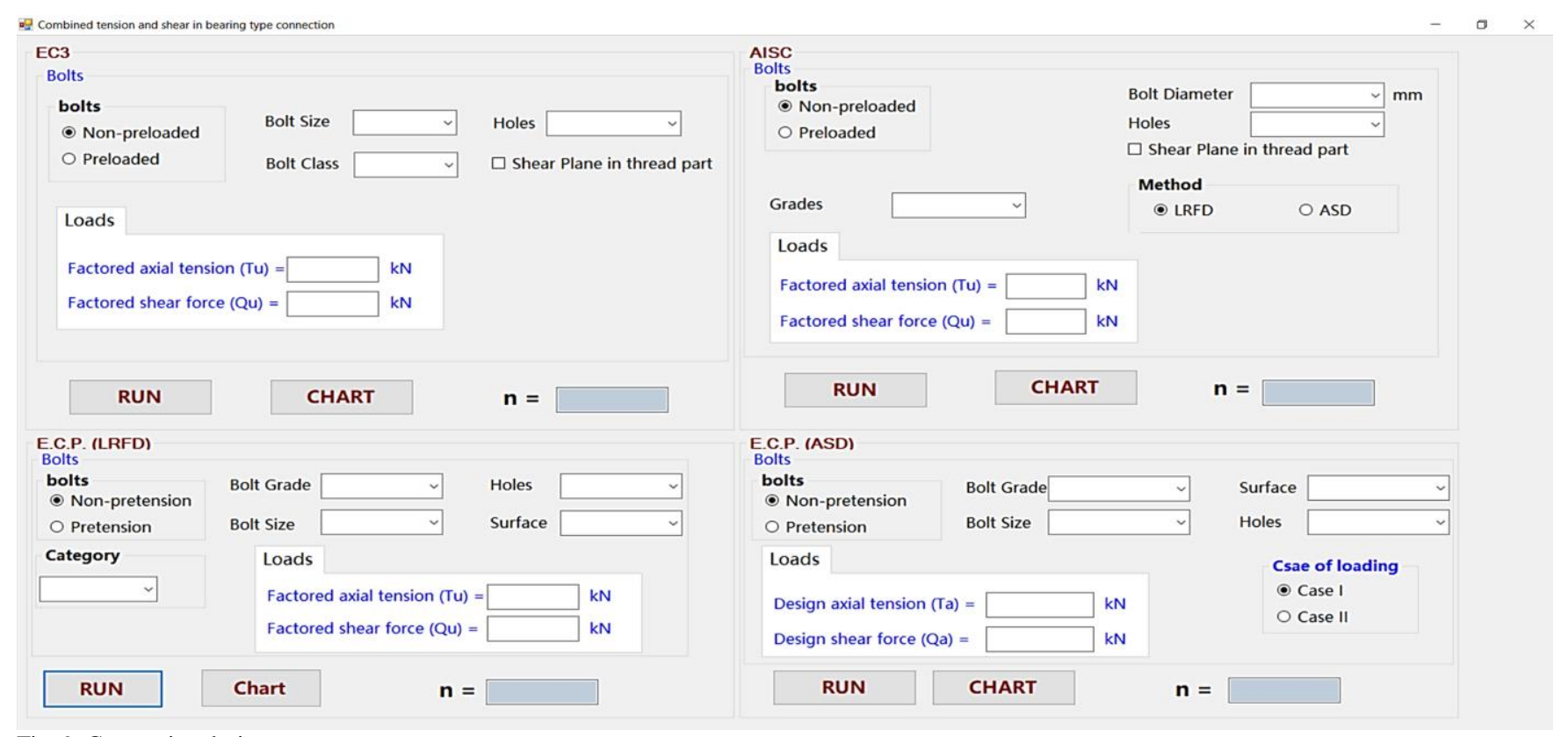

Fig. 9. Connection design program

\section{GOAL AND WORK SCOPE}

This work aims to compare and clarify variations and similarities among EC3, ECP, and AISC codes by using the design program. The program was developed using Egyptian codes (ASD \& LRFD), American codes (ASD \& LRFD), and Eurocode 3 to design connections. Input data (shear, tension, or combined shear and tension) were entered (Fig. 9), and output data (number of required bolts) were obtained.

\section{RESULTS}

This section summarizes the main findings of this research. EC3 is economical for designing bolts under shear or combined tension and shear than the other codes. For bolts under tension, AISC (LRFD) is economical than the other codes. Figs. 10-13 illustrate the relationship between shear force, tension force, and combinations of shear and tension forces and number of bolts in various codes.

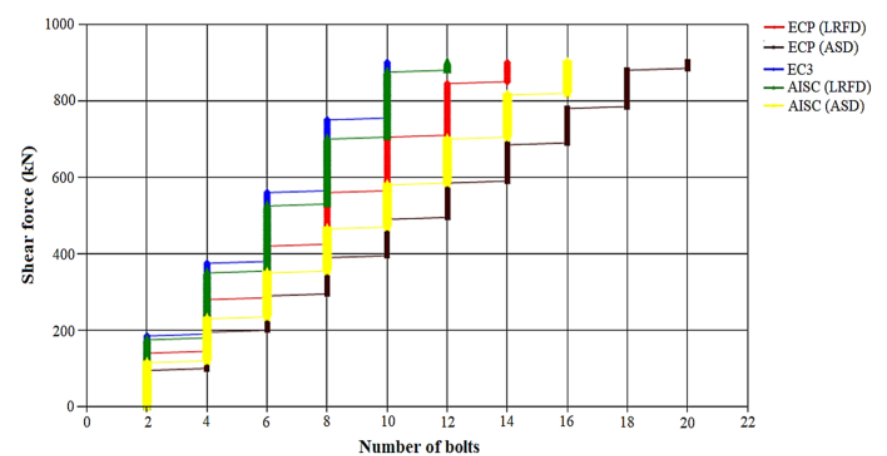

Fig. 10. Comparison of different codes in shear force and number of bolts (grade $8.8 \mathrm{M} 20$ ) 


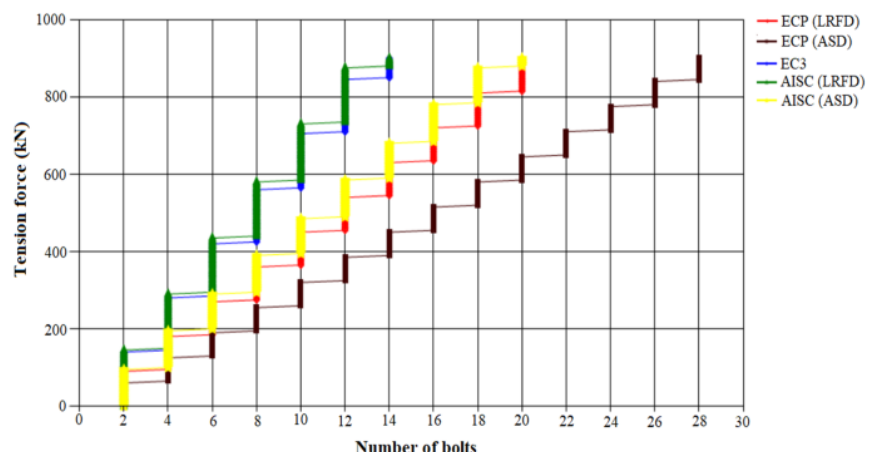

Fig. 11. Comparison of different codes in tension force and number of bolts (grade 4.6 M20)

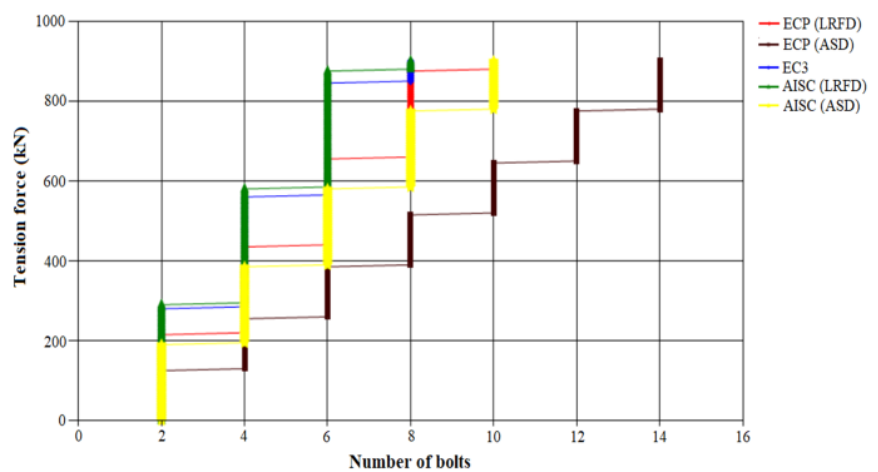

Fig. 12. Comparison of different codes in tension force and number of bolts (grade $8.8 \mathrm{M} 20$ )

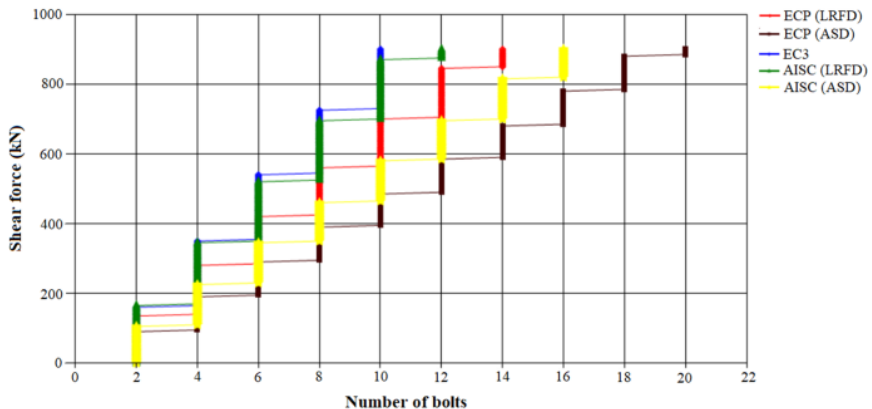

Fig. 13. Comparison of different codes in combined tension $(T=50 \mathrm{kN})$ and shear forces and number of bolts (grade $8.8 \mathrm{M} 20$ )

\section{DISCUSSION}

The results showed that EC3 in shear bolt strength is higher than other codes. By comparing among EC3 (eq. 3), AISC (LRFD) (eq. 1), AISC (ASD) (eq. 2), ECP (LRFD) (eqs. 4, and 5), and ECP (ASD) (eqs. 6, and 7), and using grade of bolt $4.6\left(\mathrm{~F}_{\mathrm{ub}}=400 \mathrm{MPa}\right.$ for all codes expect AISC $\mathrm{F}_{\mathrm{ub}}=414$ $\mathrm{MPa})$. It observes that by substituting:

$$
\begin{aligned}
& 0.25 * \mathrm{~F}_{\mathrm{ub}} * \mathrm{~A}_{\mathrm{s}}=100 * \mathrm{~A}_{\mathrm{s}} \\
& 0.6 * 0.6 * \mathrm{~F}_{\mathrm{ub}} * \mathrm{~A}_{\mathrm{s}}=144 * \mathrm{~A}_{\mathrm{s}} \\
& 0.5 * 0.563 * \mathrm{~F}_{\mathrm{ub}} * \mathrm{~A}_{\mathrm{s}}=116 * \mathrm{~A}_{\mathrm{s}} \\
& 0.75 * 0.563 * \mathrm{~F}_{\mathrm{ub}} * \mathrm{~A}_{\mathrm{s}}=174.8 * \mathrm{~A}_{\mathrm{s}}
\end{aligned}
$$

For ECP (ASD)

For ECP (LRFD)

For AISC (ASD)

For AISC (LRFD) $\frac{0.6 * \mathrm{~F}_{\mathrm{ub}} * \mathrm{~A}_{\mathrm{s}}}{1.25}=192 * \mathrm{~A}_{\mathrm{s}}$

For EC3

The results showed that AISC (LRFD) in tension bolt strength is higher than other codes. By comparing among EC3 (eq. 10), AISC (LRFD) (eq. 8), AISC (ASD) (eq. 9), ECP (LRFD) (eqs. 11, and 12), and ECP (ASD) (eq. 13), and using grade of bolt $4.6\left(\mathrm{~F}_{\mathrm{ub}}=400 \mathrm{MPa}\right.$ for all codes expect AISC $\mathrm{F}_{\mathrm{ub}}=414 \mathrm{MPa}$ ). It observes that by substituting:

$\begin{array}{ll}0.33 * \mathrm{~F}_{\mathrm{ub}} *(0.78-0.8) \mathrm{A}_{\mathrm{b}}=(103- & \\ 106) * \mathrm{~A}_{\mathrm{b}} & \text { For ECP (ASD) } \\ 0.7 * 0.66 * \mathrm{~F}_{\mathrm{ub}} *(0.78-0.8) \mathrm{A}_{\mathrm{b}}=(144 & \\ -148) * \mathrm{~A}_{\mathrm{b}} & \text { For ECP (LRFD) } \\ 0.5 * 0.75 * \mathrm{~F}_{\mathrm{ub}} * \mathrm{~A}_{\mathrm{b}}=155.3 * \mathrm{~A}_{\mathrm{b}} & \text { For AISC (ASD) } \\ 0.75 * 0.75 * \mathrm{~F}_{\mathrm{ub}} * \mathrm{~A}_{\mathrm{b}}=232.9 * \mathrm{~A}_{\mathrm{b}} & \text { For AISC (LRFD) } \\ \frac{0.9 * \mathrm{~F}_{\mathrm{ub}} *(0.78-0.8) * \mathrm{~A}_{\mathrm{b}}}{1.25}=(224.6-230.4) & \\ * \mathrm{~A}_{\mathrm{b}} & \text { For EC3 }\end{array}$

\section{CONCLUSIONS}

This study was conducted to compare design procedures with bolted connections in codes produced in various countries. After evaluating the requirements given by different codes (ECP, EC3, and AISC), the accompanying variations and similarities were noted:

- The three codes have similar strength but different names for steel grade.

- The three codes have the same bolt grade, but different names are used when $F_{u b}=400,800$, or $1000 \mathrm{MPa}$.

- The minimum spacing in Eurocode 3 is less than those in American and Egyptian codes. Ends, and edge distances in American are typically less than those in Eurocode 3 and Egyptian codes.

- Eurocode 3 provides the maximum distances, and the spacing, ends, and edge distances are typically less than those in American and Egyptian codes.

- Eurocode 3 is economical in number of bolts used to design bolted connection under shear and combined shear and tension than American and Egyptian codes. The ratio EC3 to AISC (LRFD), AISC (ASD), ECP (LRFD), and ECP(ASD) in the study cases are $(1.09,1.6,1.33$, and 1.92), sequentially, at the same of the bolt number in the shear.

- American (LRFD) is economical in number of bolts used to design bolted connection under tension than American (ASD), Eurocode 3 and Egyptian codes. The ratio AISC (LRFD) to EC3, AISC (ASD), ECP (LRFD) and ECP(ASD) in the study cases are ((1.01 - 1.04), 1.5, (1.57 - 1.6), and (2.2 - 2.26)), sequentially, at the same of the bolt number (grade 4.6) in the tension and (((1.01 - 1.04), $1.5,(1.3-1.33)$ and $(2.2-2.26)))$, sequentially, at the 
same of the bolt number (grade 8.8 and 10.9) in the tension.

- Similar elliptical expressions of interaction between shear and tension are provided by American and Egyptian Codes, whereas a linear relation is provided by Eurocode.

\section{Authors Contribution}

N.S. Mahmoud and F.A. Salem conceived the research strategies. D.A. Eltawil assembled input data, designed the program, develop program, and ran the program. N.S. Mahmoud and F.A. Salem supervised the program and conducted the observations. N.S. Mahmoud, F.A. Salem, and D.A. Eltawil analyzed the output of program. All authors discussed and validated the results and commented on the research results at all stages. D.A. Eltawil wrote the paper. N.S. Mahmoud and F.A. Salem supervised its edited the paper. All authors contributed equally to the work presented in this paper. All authors have read and agreed to the published version of the paper. This research received no external funding.

\section{REFERENCES}

[1] X. Y. Sayed A. Nassar, "Bolted connections," New York, 2013, doi: 10.1007/978-0-387-92897-5.

[2] W. L. T. Yoda, "Bridge engineering," Matthew Deans, 2017.

[3] H. A. AL-Eliwi, B. J., Ekmekyapar, T., \& Al-Juboori, "Comparison of AISC 360 - 16 and EC4 for the prediction of composite column capacity,” Int. J. Energy Eng. Sci., vol. 2, no. 2, pp. 3-22, 2017.

[4] M. S. Bernuzzi, Claudio, and Benedetto Cordova, "Unbraced steel frame design according to EC3 and AISC provisions," J. Constr. Steel Res., vol. 114, pp. 157-177, 2015, doi: 10.1016/j.jcsr.2015.07.012.

[5] M. M. H. Bakhoum, Mourad M., and Sherif A. Mourad, "Comparison of actions and resistances in different building design codes," J. Adv. Res., vol. 7, no. 5, pp. 757-767, 2016, doi: 10.1016/j.jare.2015.11.001.

[6] V. V. Gebre, T. H., Lebed, E. V., \& Galishnikova, "Comparative study of the AISC-LRFD, Eurocode 3 \& SP 16.13330.2017 steel members design," IOP Conf. Ser. Mater. Sci. Eng., vol. 675, no. 1, 2019, doi: 10.1088/1757-899X/675/1/012009.

[7] M. A. McCarthy, C. T. McCarthy, V. P. Lawlor, and W. F. Stanley, "Three-dimensional finite element analysis of single-bolt, single-lap composite bolted joints: Part I - Model development and validation," Compos. Struct., vol. 71, no. 2, pp. 140-158, 2005, doi: 10.1016/j.compstruct.2004.09.024.

[8] C. Maiorana, E., \& Pellegrino, "Comparison between Eurocodes and North American and main international codes for design of bolted connections in steel bridges," J. Bridg. Eng., vol. 18, no. 12, pp. 1298-1308, 2013.

[9] J. C. Bikoko, T. G. L., \& Tchamba, "Comparison of a steel column design buckling resistance between the South African/Canadian (SANS 10162-1:2005/CAN/CSA-S16- 01:2005), Eurocode 3 (EN 1993-1-1:2005) and Australian /New Zealand (AS4100:1998/NZS3404:1997) standards- Part I: PFC- SA (South Afr," J. Mech. Civ. Eng., vol. 12, no. 3, pp. 160-169, 2015, doi: $10.9790 / 1684-1232160169$.

[10] M. L. F and M. R. S, "Comparative study of results obtained through the aisc 360-10 and eurocode en 1993 standards for the analytical verification of long steel cylindrical members with slender sections," 2016.

[11] M. of Housing, Egyptian code of practice for steel construction (Load and Resistance Factor Design) (LRFD), no. 359. 2007.

[12] M. of Housing, Egyptian code of practice for steel construction and bridges (Allowable Stress Design), no. 205. 2001.

[13] AISC (American Institute of Steel Construction), "Specification for Structural Steel Buildings, ANSI / AISC 360-16,” Am. Inst. Steel Constr., p. 676, 2016.

[14] BS EN 1993-1-1, Eurocode3:Design of Steel Structures-Part11:General rules and rules for buildings, vol. 1. ECCS - European Convention for Constructional Steelwork, 2013.

[15] S. Topkaya, C., \& Şahin, "A comparative study of AISC-360 and EC3 strength limit states," Int. J. Steel Struct., vol. 11, no. 1, pp. 1327, 2011, doi: 10.1007/S13296-011-1002-x.

[16] European Committee for Standardization (CEN), "Eurocode 3: Design of Steel Structures-Part 1-8: Design of Joints," vol. 50, p. 77, 2005.

[17] European Standar, Hot rolled products of structural steels. 2004.

[18] R. Committee, "Structural joints using specification for high-strength bolts," vol. 2014, no. April. 2014.

[19] Charles J. C et al., "Unified design of steel structures," North Charleston, 2017.

[20] J. P. Jaspart and K. Weynand, "Design of joints in steel and composite structures,", pp. 1-388, 2016, doi: $10.1002 / 9783433604762$

[21] A. C. on Manuals, Steel construction manual AISC. 2017.

[22] F. W. Czech, "Bolts, welds, column base," Prague, 2014.

\section{Title Arabic:}

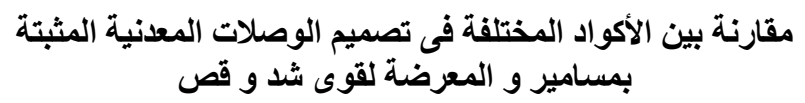

Arabic Abstract:

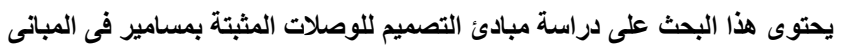

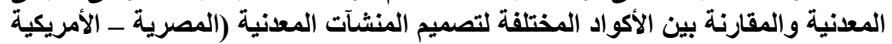

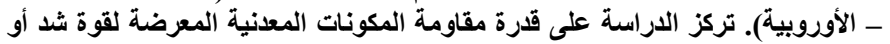

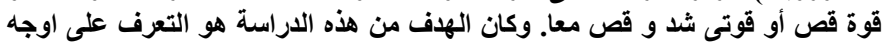

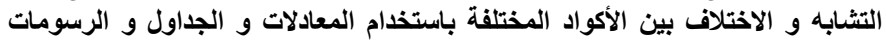

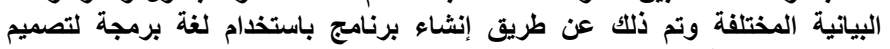
الوصلات المعدنية. 